\title{
Indigenous Identity through Hybridity and Humor: A Postcolonial Reading of Robert Merritt's The Cake Man
}

Parvaneh Ganjtalab Shad*

Islamic Azad University, Tehran Central Branch, Iran

Corresponding Author: Parvaneh Ganjtalab Shad, E-mail: shad.parvaneh@gmail.com

\section{ARTICLE INFO}

Article history

Received: July 04, 2018

Accepted: August 18, 2018

Published: December 01, 2018

Volume: 7 Issue: 7

Advance access: October 2018

Special Issue on Language \&

Literature

Conflicts of interest: None

Funding: None

\begin{abstract}
The major thrust in this research has been in the area of postcolonial studies. As one their primary missions, post-colonial works of art relate stories as seen by the oppressed and the colonized. Beginning with Edward Said's Orientalism, postcolonial figures as diverse as Franz Fanon, Gayatri Spivak, and Homi Bhabha emerged and each targeted an aspect of postcolonial conditions. The present article was undertaken to trace postcolonial elements of "colonial negotiations," and "hybridity" in an Aboriginal play by Robert Merritt entitled The Cake Man. The central argument of this article is that in its anticolonial stance, this play discusses issues of Aboriginal race and identity. To realize this argument, the play is studies with the background of Edward Said and Homi K. Bhabha's theories. While these two figures are the leading theoreticians of the research, Aboriginal anticolonial strategies, like Aboriginal humor and figurative emasculation, are also pointed out. In fact, the novelty of the study is in its amalgamation of Western theories and Aboiginal strategies. All through the play, history as seen by the oppressed becomes the focal point, making it eligible to be called postcolonial works. Merritt's The Cake Man, which is a well-known example of forced conversion, contains a very prominent manifestation of Said and Bhabha's colonial negotiations. In addition, by creating an anticolonial character in the play, Merritt highlights and criticizes colonial Christianity, colonial otherization, and figurative emasculation of Aboriginal men in Australian society. All these issues, as the play leads the audience to believe, contribute to the realization that colonial discourse has the policy of obliterating Aboriginal traditions.
\end{abstract}

Key words: Robert Merritt, Edward Said, Homi K. Bhabha, Colonial Negotiations, Hybridity, Humor, Figurative Emasculation

\section{INTRODUCATION}

Compared with any other stage in their history, today Australians are more concerned with their own past. This preoccupation with the past has occurred in two paradoxical dimensions: first the honouring of the country's history, and second an increasingly sense of guilt and blame over their ancestors' treatment of Black Australians. Reactions to the latter have also occurred in two paradoxical ways. Some identify and also commiserate with this feeling of guilty responsibility, while others contend that Aborigines should become more tolerant and forgiving of past injustices. The latter adopted stance has piqued many oppressed native minority groups in Australia, among which Aboriginal writers stand out. These writers, who believe they ought not to shy away from probing the past, have heeded Kevin Gilbert who says "Yet, cut off a man's leg, kill his mother, rape his land, psychologically attack and keep him in a powerless position each day - does it not live on in the mind of the victim? Does it not continue to scar and affect the thinking? Deny it, but it still exists." (Shoemaker 128) Therefore, Aboriginal Austra- lian Literature is now extremely preoccupied with the theme of past injustice and also with an emphasis upon the concept of a revered, self-sufficient, Aboriginal history.

In this contemporary movement, a prominent playwright stands out whose work has become the classics of the genre: Robert Merritt with The Cake Man. In this play, Merritt depicts the Aboriginal past, colonialism and its aftermaths on the lives of his characters in contemporary Australia. To investigate the resisting nature of this play, the intended research aims at applying Postcolonial method of reading on Merritt's play in order to investigate its politics of postcoloniality. Therefore, the central research problem is to investigate what antivolonial strategies the playwright adopts to communicate the silenced voice of his fellow aboriginal race. To answer it, Edward Said and Homi Bhabha's ideas can contribute to a better understanding of the play. Also, it is explored to what extent the playwright deviates from $\mathrm{Ab}$ original conventions to read an equilibrium for black/white binary. It is remarkable that the historical air of Merritt's play "is established by its locale and action far more than by its dialogue and represents a strong indictment of the New 
South Wales Aboriginal reserves (popularly called missions) as they were thirty years ago." (Shoemaker 132). While in many of Aboriginal writers' drama, subalterns are made to speak in their native language and Aboriginal music and traditions are revived, Merritt's drama lacks revival of such traditions and strikingly in some scenes the subalterns are either dumbfounded or dead. Such a choice of language seems to be contributing to the techniques he uses in his play. To investigate such issues, this research adopts European and Aboriginal postcolonial key terms like "colonial negotiations," "hybridity," "figurative emasculation," and "humor."

\section{THE COLONIAL NEGOTIATION}

Like other genres in Black Australian literature, Aboriginal plays explore such features of Aboriginality as endurance, pride, protest, poetry, sorrow, anger and humour in their dramatized stories. Aboriginality is indispensible with postcolonial struggles. It is the legacy of traditional Black Australian culture. It indicates movement towards the future while preserving the pride and poise of the past. It is counter-cultural in European terms: a response to the oppression of White Australian society. This may result in an Aboriginal self-image which has the latent power of being highly recalcitrant and against the law. Robert Merritt talked about this alternative way of searching for identity in the following sentences:

It suits society's purpose to give government mandates to build filthy institutions that keep Aborigines in prison. If you want an identity today ... if you're sick you'll get a band-aid, and you're an Aborigine - and everyone knows about ya. And if you're a drunk, or if you're a crook, you'll get a two-bob lawyer that's been out of law school for five years. You've got an identity. If you want to be a normal person there's no incentive in life whatsoever for ya ... To break the law now - it's a substitute initiation. (Qtd. in Shoemaker 232)

Therefore, Aboriginality is both an inheritance from Black Australian past and a direct, sometimes vehement response to the Black Australian present. Such anti-colonial stance is easily visible in the structure of Merritt's The Cake Man. Temporally, the play depicts both the past and the present and its stress on Black Australian history is a vital constituent of the conception of Aboriginality. In the first scene of the play, readers are confronted with the process of colonization inflicted on an Aboriginal family, consisting of a man, a woman, and their son. In the stage direction, Merritt depicts how serenity governs in their surrounding: "Earth, water, sky: nature at ease." The three Aboriginal characters hunt, play, and laugh and finally "All three embrace. They sit contentedly together, requiring no more" (5). But, by the entrance of colonial agents, this serenity is shattered. "Staring in alarm" (5), the Aboriginal family sees a priest, a soldier, and a civilian approaching them. This confrontation is something that is elaborated all through the first act. Such a situation is what makes Homi Bhabha's ideas different from Edward Said's. Bhabha contends that Said's analysis of the colonial encounter is unidirectional: it only sees colonial authority as taking place from the colonizer to the colonized. Said's contention also puts forward that the iden- tities of colonizer and colonized are fixed and unchanging. Bhabha believes that colonial discourse is in fact conflictual, ambivalent, and full of contradictions. The Contradictory psychic relationships between the colonizer and colonized moving, for Bhabha, between fear and desire for the Other precludes any fixed, unchanging identities for the colonizer and the colonized. The connection between the two is one of negotiation and transaction, and not a unidirectional will to power as Said suggests (Nayar 27). In The Cake Man, this propensity for negotiation is easily noticeable in the first encounter between the priest and the Aboriginal family:

PRIST: Greetings! And God's blessing. I bring you good news! Here it is my child, [offering the Bible] for you and little family. And this also I bring to you [wagging the cross] and to your people. The gift of love. The promise of salvation. Yours. (6)

In response, the Aboriginal man shields his family and does not answer. This resistance makes the priest and his associates change their discourse to find a way to attain their goal, as indicated in the stage direction: [They regard the ABORIGINES thoughtfully. The ABORIGINES regard them fearfully.]. While the colonial agents are angry with the ignorance of the man, once again the negotiation between the two happens:

CIVILIAN: Here, I'll reach them with my pretties.

[He steps forward, reaching in his bag to bring forth bright beads, ribbons, and so on. He offers them in a coaxing way to the MAN, WOMAN, and BOY. They step back from his pretties.] (7)

The civilian acts as a second person after the priest who tries to further the colonial mission through negotiations. Like the priest, the civilian makes an attempt to attract the Aboriginal family through "his pretties." By offering things "in a coaxing way," he proves himself to be against unidirectional strategies. But, again due to the resistance of the colonized, the colonial negotiation fails. As their last option, the colonial agents are compelled to have recourse to force, a fact that makes the priest express his regret:

PRIEST: Alas! I have failed.

CIVILIAN: Don't blame yourself, now.

SOLDIER: Aren't the two of us here, Father, both witnesses to your patience?

PRIEST: Bless you, bless you both. (7)

What is obvious in these lines is the religious justification of the colonial agents. We can easily notice how the priest uses religious discourse when the negotiation fails and how has to use it in his recourse to unidirectional strategy. The religious discourse in the play has always been an indispensible target in Aboriginal postcolonial literature. Anticolonial writers like Merritt believe that Christianity did not bring them the peace it claimed. Moreover, as Wheeler points out, they argue that "The imposition of a foreign religious system on Indigenous people is meant to destabilize their cultural bonds and shake the trust in their identity and culture" (131). This idea was best encapsulated in a poem by Oodgeroo Noonuccal, the national Aboriginal poet, entitled The Dispossessed:

Peace was yours, Australian man, with tribal laws you made, 
Till white colonials stole your peace with rape and murder raid;

They brought you Bibles and disease, the liquor and the gun:

With Christian culture such as these the white command was won.

A dying race you linger on, degraded and oppressed, Outcasts in your own native land, you are the dispossessed. (Noonuccal 95)

Noonuccal's poem is an explicit expression of the hardships endured by the Aborigines. As Noonuccal points out, they include territorial, religious, and cultural. Such hardships are also reflected in the play. The "murder" mentioned in Oodgeroo's poem befalls finally on the Aboriginal man in The Cake Man, when as the colonizer's final solution "The SOLDIER shoots the MAN dead." Then, when the soldier tries to take the Aboriginal man's family by force, the colonial negotiation once again becomes the first priority:

SOLDIER: Leave it to me, Father. [He starts a purposeful move.]

PRIEST: No, let me try again. [Wheedling] Come? Will you not come now out of darkness into the light? No? (9)

Priest's assertion, "let me try again," and the stage direction, "Wheedling" again indicate the priority of negotiation in the play. This is supported by the fact that whenever a force (or unidirectional strategy) is to be applied by the soldier, its permission should be given by the priest as the symbol of negotiation, like this extract when the soldier says "Leave it to me, Father." The colonial negotiation becomes more manifest, when after believing that the woman and the boy don't understand him, the priest expresses his inner dialogue:

PRIEST: [Shaking his head, smiling sadly] Oh, you poor savage devils, you don't understand, do you? (9)

The priest's inner dialogue shows that his "wheedling" is not out of compassion; rather it is solely for the sake of negotiation. At last, after many arguments of force and negotiations among the three colonial agents, the Aboriginal family consents to go with them. This happens when the woman takes the Bible offered by the priest:

PRIEST: There, take it and keep it always. Keep it, and from it learn wisdom, and faith, and love.

[Together with the SOLDIER, he starts to shepherd the WOMAN and the BOY off the stage.]

Come... don't be frightened. Put your trust in us. we're going to make you our own. (11)

The colonizing statement "we're going to make you our own" does not, however, become true of the Aboriginal man, who is left on the stage. After that they exit, "the Man opens his eyes and gets groggily on his feet", symbolically signifying his anticolonial mission, as well as the endurance of the Aboriginal entity and culture.

\section{SWEAT WILLIAM AS A TYPICAL ABORIGINE}

All through the play, the surviving Aboriginal man, who in the second act is called Sweat William, shows signs of resistance to the colonial hegemony. The fact that he stood upon his feet after being shot to death can indicate his presence as a symbol of resistance. William shows his resistance in many ways: the songs she chooses for reciting, the way he regards colonial agents, and the way he talks about colonial missionaries and religion. William's initial presence after being shot is accompanied by singing a song. In the second act, before he enters the house, William sings an Aboriginal song off stage:

SWEET WILLIAM: Ohhhh, Ned Kelley was born in a ramshackle hut,

He battled since he was a kid.

He grew up with bad men and duffers and thieves,

And learned all the things that they did. (24)

What he sings about is an Australian legendary figure, or, according to Bea Brear in Green Left Weekly, what some regard as Australia's equivalent of Robin Hood. By singing this song, Sweet William shows himself in favor of his past heritage and culture, and uses this favor as a reaction to the dominant ideologies of his society. In postcolonial studies it is believed that colonial cultures and nations must resist the effect of European humanism "if they are to foster an independence of mind that can lead to the revival of old, or the creation of new, local cultures" (Hawley and Nelson 238). Similarly, William's postcolonial stance is in fact an attempt to revive his true identity, an identity which has been deterred by Christian hegemony in the play.

In other scenes, there are other instances of the revival of Aboriginal cultures by William. His allusion to the bushrangers and Jimmy Governor, Australian anticolonial people, reminds the audience of the Aboriginal identity. These allusions, however, torments William since he believes that they are narrated to point out his inaction:

WILLIAM: Pumpkinhead... he don't want no stories about the Kuri bushrangers. not 'cause he likes me tellin' him stories, Rube. No, that boy he makes me tell about when the Kuris were brave, and he's only meanin' to make me know about myself.

RUBY: What?

WILLIAM: You know what, Rube... about me, I ain't never stuck up no white man, and I ain't done not one thing in my whole life is brave. All my life, all I ever done was to be a jacky-boy. (34)

William's concern with his son, Pumpkinhead, may signify the playwright's concern with future generations of Australian children. William is afraid that since he is a bad model for his son, and since he himself is not a true follower of Aboriginal heroes, it may negatively affect his son, or future Aboriginal generations. All through the play, William's revival of Aboriginal culture and regret for inaction is concomitant with a rejection of colonial hegemony. While confiding the audience at the end of the first act, Sweet William decries against the Christian hegemony in his society, which is utterly foreign to him:

Rube, my missus, she's always thankin' Christ for everythin'... anythin'... nothin'. Her an' that fuckin' book. [With a laugh] She heard me say that, I'd be in strife. Christian she is, my old lady, a mission Chrishyun, the worst kind. (12) 
The woman he calls Rube is in fact his wife who in the second act has found a name, since, as stage direction satirically puts it, she is "now civilized" (18). As Sweet William's foil, Rube has become a Christian subject and like the priest plays the role of a missionary. This ideological conflict between the wife and husband is a prominent feature throughout the play. As its postcolonial politics, The Cake Man is deliberately anti-missionary and, thus, against forced conversion. To Merritt's understanding, the Church has bolstered the efforts of government to remove all the authority of Aboriginal men: together the two have, in figurative terms, emasculated them (Shoemaker 135). This is highly evident in the opening of the second act where their son, Pumpkinhead, is reluctant to regard Sweet William as his father:

PUMPKINHEAD: Um. Pub shut down. Sweet William comin' home.

RUBY: Don' call your father that, I tol' you!

PUMPKINHEAD: Your husban' be home soon then.

RUBY: [angrily] You call your father your father. [More angrily as he ignores her] You hear me, you cheeky little bugger. (20)

This extract shows how the image of father has been destroyed as a result of colonial emasculation of Aborigines in Australian society. In a society where the economic pillar of family, father, is marginalized and becomes poor, he loses his paternal stance in the eyes of his family. This colonial policy is felt by Sweet William when he laments:

But, Rube, there ain't nothin' now I know to do. Just hopeless, and no price I can pay because there ain't no price I've got to give that anyone wants. I've got nothing they want!

William's comment is a vitally historical one. It is Ruby in the role of the wife and mother that literally holds the family together - not her husband. Her greater strength of purpose is as a result of her religious devotion; Christianity is a crucial support or consolation. But, according to Merritt, this analysis is wrong, for he believes that the Bible commands her to be passive - to receive God's lot obediently - and this ensures that she will never forsake the mission system. Merritt feels very powerfully that Christianity has been:

the most destructive force that has ever hit the Aboriginal people. And, to be quite truthful - I mean it's sad to say this -... I think that if religion has enabled them to survive for 200 years they probably would have been better off ... being killed, wiped out, annihilated ... You can't even say it's Christian charity; it's a sick interpretation of a sad political philosophy. (qtd. in Shoemaker 135)

As the play shows, Merritt's criticism of religious colonization is dramatized in Sweet William's life. On the other hand, the play the problems of a family whose father resists colonial hegemony and whose mother embraces. Considering the extravagantly religious obedience of Ruby and William's idea of going to Sydney as a salvation, Shoemaker calls The Cake Man a play built upon often "bitter illusions" (Goetzfridt 282). While Ruby's religious commitment does give her the power to keep her family together in spite of the despondence and near-alcoholism of her husband, it also commands her to receive the will of God without question.
This manifests itself in the play when Sweet William actively challenges Ruby's passivity:

WILLIAM: Huh. You prayin' again, Rube?

RUBY: Now don't you go talking like that, Sweet William. That's why we never have no luck all the time. Do you good, to read this book, that's where I get my strength from in every day, truly is.

WILLIAM: Couldn' do me no more good than a smoke would right now, Rube. Or a little drink.

RUBY: Don't want you talkin' like that in the presence of this here good book, Sweet William! (28)

Since Sweet William proves to be more obstinate, Ruby becomes active in defending what has made her passive. In fact, these two figures become symbols of anti- and pro-colonialism in the play:

WILLIAM: Rube, I'm sick of hearin' you tell the kids damn stories that ain't never comin' true. All about Jesus loves us, and how one day we're gonna find the Cake Man...

RUBY: Jesus is true. Cake Man is true. Shut up.

WILLIAM: Ah, Rube... ain't no Jesus, ain't no man who... They just stories.

RUBY: Shut your wicked mouth, Sweet William! (33)

These dialogues demonstrate the extent of Ruby's subservience to a religion which is at the service of a colonial power. Ruby has become so affected by colonialism and so biased that she has lost her power of reasoning. Commenting on this aspect of Ruby, John Newfong's states that "she is only strong because she believes more devoutly in her own fantasy. So whether you call that strength or an illusion of strength, I don't know. Sweet William at least believes in his own potential. And Ruby, because of her Christian beliefs, undermines his beliefs in himself because she doesn't dare believe in herself' (qtd. in Shoemaker 242). Newfong's analysis can best be shown in the play when William cannot get a strong confirmation of Ruby in going to Sydney:

BUBY: Sweet William, you have to think about what you want. got to decide, and you don't ask no woman of yours what you gonna do, but you can tell me what you gonna do and I'll know that's right and you gotta do it and I know you will do.

WILLIAM: You really think that, Rube? You do?

RUBY: I tell you so.

WILLIAM: Ah, Rube, you tell me so. [Wryly] But you don't tell me what you know, about how you feel, I never heard you tell the truth about me yet.

RUBY: Yes you just did.

WILLIAM: I just heard you tell what a good woman you are, Rube. pretendin' I'm not no good.

[Pause.]

RUBY: You sayin' I told a lie, Sweet William?

WILLIAM: Just a white lie. But I know Rube. (33)

The dilemma between the couple runs through the play. In spite of all these, Sweet William also lives his life in a fantasy world. As his attempt to break with his marginalized situation, he manages to assure himself and, importantly, his son Pumpkinhead, that his chief decisive action of moving to Sydney will be the salvation of the family:

Rube, I'll just go down to that Sydney, I'm gonna be lucky and get a job and find somewhere that's gonna be 
ours, and soon buy a big red house like Pumpkinhead wants and clothes and a 'lectric iron for you, 'lectric light, too, and plenty of tucker for the kids that we could buy out of my good job I'll get. I can work, Rube, you know I can. Job, that's all it needs. (32-33)

This vision is a significant one: not only is it uttered in Western, materialistic terms (which shows the degree of Sweet William's hybridity) but Merritt makes it clear that the character has no opportunity to fulfill his dream. As a result of no mistake of his own, William is arrested because he is standing near a pub door when the police come to suppress a brawl. According to Brian Syron, who has directed and acted in a number of productions of The Cake Man, what is important is not the arrest of the father but the instilling of hope and pride in the son. In his view, the key is Sweet William's decision to try and break out of the institutionalised degradation of the mission system: "The sons of the father will be perceptive even if the father is not" (qtd. in Shoemaker 259).

Pumpkinhead is to be the expectation and the tool of change for the future. Newfong adds that Sweet William's success was not just a secondhand one, but principally consisted in his action to break with what he terms the "black matriarchy", which embedded by colonialism had resulted in his helplessness. As he puts it:

When one society is dominated by another society and the dominating matrix of society is male-dominated, the men of the dominated society will be emasculated. And it's almost a subconscious thing, you see. You notice that in The Cake Man the mission superintendent and Inspector ... defer to Ruby - this is to further undermine William's standing, simply by not addressing themselves to him. And this is what is always done. (qtd. in Shoemaker 260)

While it is true for him to maintain the way in which sexism can strengthen racism, his suggestion that the only actual Black Australian spokespeople are males is challenged by the accomplishments of several Aboriginal women. It is questionable that the actual causes of the fragile self-image of Aboriginal men like Sweet William are that he has been deterred as a father from providing for his wife and children by unemployment, the institutional prejudice of Aboriginal reserve managers and the bias of White Australians.

\section{HYBRIDITY AND CULTURAL NEGOTIATION}

As expounded in the second chapter, Bhabha in his The Location of Culture emphasizes that cultures are hybrid, simply referring to "the mixedness, or even 'impurity' of cultures - so long as we don't imagine that any culture is really pure" (Huddart 6). This term refers to an original mixedness within every form of identity. Concerning cultural identities, "hybridity refers to the fact that cultures are not discreet phenomena; instead, they are always in contact with one another, and this contact leads to cultural mixed-ness" (Huddart 7). Considering this aspect of his culture, Sweet William expresses his regret for the loss of his true identity in his soliloquy at the end of the first act when his family and the colonizers exit:
MAN: Uh, who you? [Grinning craftily] hey, listen, you wanna buy a boomerang? [He pulls one from under his coat and holds it up for audience inspection] Good one, this is. [Turning it over, reading the back of it] Made in Japan [with a grin] by our trading allies. [Tossing the boomerang off the stage] (12)

The fact that a traditional tool of Aborigines, boomerang, is made in Japan indicate the state of hybridity in the play. The use of the word "grin" in the stage direction and William's act of "Tossing the boomerang off the stage" are signs of his dissatisfaction with hybridity. In the process, Sweet William's criticism of the hybridity of cultures leads to a criticism of the hybridity befallen on him himself:

MAN: See'n I'm a Kuri. The Australian Aborigine, that's who I am and what I am. made in England. (12)

And more directly:

MAN: The Australian Aborigine-that's me-stands in danger of losing his identity. (13)

While Bhabha regards hybridity as a positive way for resistance, William initially sees it negatively and tries to revive his original culture. But, in a hybrid culture, endeavors to revive an original identity are doomed to failure (Runions 94). Having this principle in mind, Merritt makes Sweet William believe that his original culture will not be back: "Me boomerang won't come back" (16). Even in the last scene when like the first act he addresses the audience directly, Sweet William restates this notion in a more direct way:

SWEET WILLIAM: No? Ah, well it don't matter. Please don't give it another thought. Forget all that shit they say about giving me back my culture. That's shit. It isn't what I'm really after, not really. (58)

As William's later dialogue indicates, Aboriginal authors like Merritt are not after a thorough revival of an original culture. Since cultures have been hybrid and it is difficult to disentangle them, this mission will be impossible. In fact, by highlighting some aspects of their Aboriginality, these authors look for an opportunity to call for "justice and land rights, challenge racist stereotypes, dismantle exclusionary models of national identity, and correct biased historical narratives of progress and peaceful settlement" (Webby 29). Surprisingly, this opportunity is provided by hybridity. According to Runions, "Bhabha envisions hybridity as a step toward freedom, using the very disavowal that hold discrimination in place and that does not allow for the full play of cultural difference. Hybridity can be used to reread and reorder dominant discourses, allowing for subaltern voices suppressed in the stifling of difference" (95).

In Merritt's The Cake Man, hybridity in Ruby's neighborhood allows his son to enter a dialogue with his white playmates, whom he calls "gubba". In his interaction with "gubba kids", Pumpkinhead realizes that the myth of the Cake Man is something fabricated:

PUMPKINHEAD: Arr, ain't no Cake Man, Mum.

RUBY: There is so too! [Pretending to be cross] Now you stop that, little Pumpkinhead, there is so.

PUMPKINHEAD: No, there ain't.

RUBY: [firmly] Ain't no birriks, is what there ain't. You sayin' believe in silly ghosts but no Cake Man?

PUMPKINHEAD: Gubba kids said there ain't. They tol' me and Collie and Noelie and Collie's Sissy. (23) 
The information Pumpkinhead gets through the hybrid society enrages Ruby, the colonial agent at home, and this proves how hybridity is advantageous for the colonized people and how is disadvantageous for the colonizer. Surprisingly, Pumpkinhead's information comes from the children of white people who have implemented such ideologies in Australia. This information, which is finally revealed to be fictitious, has changed into a myth throughout the play. Since power-knowledge in Australian society has buttressed the white's beliefs, Pumpkinhead takes gubba kids' expressions for granted:

RUBY: Gubba kids! How they know, them kids?

PUMPKINHEAD: No Father Christmas, they know that. They knows, 'cos they's gubba. That Ralphie knows.

RUBY: I ask you how? Gubba kid just a kid, same as you are and Collie and Noelie.

PUMPKINHEAD: Ralphie knows. He said you buy toys from the shop and when mothers got no money ain't no Santa gonna come to no Kuri kids.

RUBY: Oh!

PUMPKINHEAD: An' I seen the money name tickets on all the toys too, I have, and me and Rubby ain' got no toys, so that's why no Father Christmas. only got birriks I can see. (23)

In this extract, hybridity results in a disclosure of a truth hidden by colonial discourse. In fact, the dialogue shows another fictitious story among Aboriginal people. Pumpkinhead points to the fact that Santa never comes for poor children in his neighborhood, a point supported by Ralphie who has revealed to Pumpkinhead "the money name tickets on all the toys" (23). This disclosure occurs as a result of the colonizer and the colonized coming together. In other words, all these revelations, according to Bhabha, owe to the "third space" which appears as a result of hybridity (Huddart 85).

Another figure who contributes to the "third space" in the play is Uncle Foley. Uncle Foley never appears onstage and he is mostly remembered by Sweet William. He is a character who acts as a source of Aboriginal inspiration for William:

MAN: Well, Uncle Foley can tell you them Dreamtime stories. Oh, gahd, jeezus, he knows how everythin' started off once. (14)

All through the play, the dreamtime is abundantly mentioned by William. In fact, this mentioning is an anticolonial strategy applied by William. The Dreamtime is the idealized or fictionalized conceptions of Australian mythology (Knudsen 5). This theme is frequently referred by Aboriginal authors in Australian literature since its conceptions act as a resistance to colonial discourses. In a scene, Ruby, who has become a colonial agent, shows how Dreamtime is neglected in favor of Christianity:

RUBY: Long time ago, when Dreamtimes ending, Jesus, he sent the Cake Man over the sea to find the Kuri children. And he come... (21)

As a person affected by colonial subjugation, Ruby regards Dreamtime as a finished culture. In addition, like colonial discourse, Ruby replaces Dreamtime with Christian stories. Thus, since Ruby and Uncle Foley are representatives of these two conflicting discourses, Ruby shows her detestation of Uncle Foley and asks her son to avoid him. This may better indicate Ruby's stance as a colonial agent: RUBY: Uncle Foley! That liar ol' man! [Softening] Oh, now don' you listen to no gubba kids or no silly old men. [Reassuring] Your Ruby tellin' you there sure is a Cake Man. Jus' gotta find the feller. (23)

In this dialogue, like colonial negotiations, Ruby tries to make use of negotiation as a strategy to calm her son and to gain his favor. This claim is supported by the use of the words "Softening", "Reassuring", and "Your Ruby" in the play. In another attempt to stand against Aboriginal discourse, Ruby again states her hatred of Uncle Foley between the lines when talking with Sweet William:

WILLIAM: I been all over the bloody mission, haven' I, tryin' to get a draw, an' I'm plain buggered.

RUBY: You're a sad man, Sweet William.

[She gets up and takes the Bible to the bedroom.]

WILLIAM: Humph. I say I am.

[He gets up and starts to wander about the room.]

I don' know, Rube, buggered if I do. Man's been all around, everywhere. nothin' bloody doin'.

RUBY: [off] You try your Uncle Foley? (28)

The attitude of Ruby as a colonial agent towards Uncle Foley is an instance of a process called "Otherization". "Otherization" is a loosely reductive process that attributes an imagined superior identity to the Self and an imagined inferior identity to the Other. According to Kumaravadive$\mathrm{lu}$, "There is general tendency among individuals and communities to portray themselves as having an identity that is desirable and developed while presenting the identity of people who are racially, ethnically, or linguistically different as undesirable and deficient" (16). In an attempt to react to this process, some of Aboriginal writers asked for an equitable unification of blacks with whites. This attitude is expressed in the most direct way by Oodgeroo Noonuccal, the Aboriginal national poet:

We want hope, not racialism,

Brotherhood, not ostracism

Make us equals, not dependants.

We need help, not exploitation,

Homes, not settlements and missions.

We need love, not overlordship,

Grip of hand, not whip-hand wardship. (Craven 1)

In Merritt's The Cake Man, this policy is also applied. When it is revealed that the thief of the civilian's coals was Pumpkinhead and when the civilian sees the Aboriginal family's household, he sympathizes with the family and returns with a big cake to compensate for his charge. In other words, Merritt's play urges white people to see how Aborigines live their lives and sympathize with them.

\section{HUMOR AS AN ABORIGINAL POSTCOLONIAL STRATEGY}

A survey of the Aboriginal plays written so far shows that nearly all of them depict scenes of privation, gloom, poverty, discrimination and even death, but none of them is unre- 
lievedly serious in tone. Humour mitigates the seriousness of these plays and at the same time increases their impact; it releases them from any threat of being repressive in tone (Goetzfridt 282). Commenting on this matter, Jack Davis states that black drama usually demonstrates a wide variety of emotions:

Don't just show them [the audience] the comic side of life right through ... show them sadness, pathos, gladness, happiness, sorrow, and all the in-between ... all those emotions. (qtd. in Shoemaker 234)

As a confirmation of Davis's remarks, Stanner, the Australian anthropologist, argues on the subject of humour in both of its the general and particular facets. Obviously there are circumstances and occasions which both White and Black Australians find funny:

the hammer on the thumb, the slip on banana peel, the sudden loss of dignity - all these 'reversals', the basis of a universal class of humour, evoke much the same responses among the Aborigines as among Europeans. (Stanner 270)

But, as Stanner states, there is an additional class of humor which appears to be particular to Aboriginal people. Though it is challenging to delineate in precisely, Black Australians have specified some of its features:

The humour of western culture, because western culture is competitive, is itself competitive ... You'll find that amongst traditional Aboriginal people ... 'put down' humour is not seen as all that funny. [They have] the humour that is often one of endearment, often one of familiarity ... it equates people with other people, people with animals and what have you ... you'll find that even in urban situations Aboriginal people can recognise somebody way down the street by the way they walk. Because they know people's walks and mannerisms. And those things are more noticed by, and more remembered by, Aborigines than they are by white people. (qtd. in Shoemaker 234)

The humor found in Black Australian drama originates from the conducts and particular abilities of Aborigines, particularly those of mime and impersonation. Jack Davis has given a brilliant instance of these capacities in the marginal situation, and has revealed how they can appear in Black Australian drama:

You see, we've always been acting. Aboriginal people are the greatest actors in the world ... We've acted up before magistrates, we've acted up before the police, we've acted up before social workers; we've always done our own mime ... Like the man who burns his feet and he doesn't even know his feet are alight. He's standing on the fire and he says [imitating voice] 'By Crikey, I can smell somethin' burnin' there! You fellas burn an old bag there somewhere? Or you burnin' kangaroo skin?' [New voice] 'Uncle! You're standing in the fire. Get out of the fire there!' He never wore boots for forty years and he's got callouses on his feet that thick, and he was standing in the fire. His feet were burning and he didn't even know it! And laughed - you know that, [claps]... that went around the camp for a week. Well, little incidents like that, you know, that carry on all the time - it's not very hard to put 'em down on paper. I'm sure the Aboriginal playwrights have seen that. (qtd. in Riemenschneider and Davis 152)

The same point is also emphasized by Robert Merritt when asked about the humor in his play The Cake Man: "Well, there's humour in the people ... no one's looked at it before ... it's beautiful" (Shoemaker 235).

While the idiosyncratic Aboriginal predisposition to humor is evident in present-day black theatre, its origins are in the tribal/traditional scope. Stanner pointed out this issue among the traditional and semi-traditional Aborigines with whom he subsisted and worked for many years. He recounts the response of an old man, one of the last existing members of his tribe, to his question, "In a few years you will all be dead; there will be no blackfellows left; but you laugh about it. Why do you laugh? I see nothing amusing":

He would not be drawn for some time. Finally he said,

'Bye-and-bye, altogether blackfellow dead. Plenty white man sit-down this country. White man walkabout longa bush. Him losim himself longa bush. Altogether white man try findim. Altogether white man losim himself longa bush. No blackfeller. Can't findim. Whitefeller dead. Blackfeller dead.' And he smiled sardonically. (Stanner 269)

Moreover, Stanner highlights the endurance of comical stories coming from everyday experiences among Aboriginal people. Among remarkable cases, he and Charlie, an Aboriginal friend, shot a barramundi lying around in a pond - which someone else had already caught:

We had touched the depths. To shoot a caught fish tied up to the bank by a string. Jarawak saw that the tale spread. The blacks never forgot it. To this day, half a lifetime later, they still laugh. When I go fishing with them, someone is sure to say in an innocent tone, 'You got plenty bullet?' (Stanner 271)

The humour Stanner refers to still is at work and is given expression in Black Australian drama, including The Cake Man. Like other Aboriginal plays, The Cake Man is a play with topical issues of Aboriginality. It advances various socio-political questions which draw upon Aboriginal male/female interactions, activism, and the Black Australian self-image. Many facets of Aboriginality are raised in Merritt's play: dejection, family intimacy, the hazard of alcohol and the preservation of pride - or at least the potential to be proud. The possibility for a constantly cynical atmosphere is adroitly offset by the playwright by way of the use of humor. The humor of Robert Merritt is less impetuous and explicit than some of his fellow Australian playwrights, but it is derivative of similar sources: it is principally the humor of "sacrilege", of the bottle and of sexual suggestion (Goetzfridt 282). Sweet William frequently targets organised religion:

What's that bit again? 'For y'travel over land and sea to make one convert ... an' when ya finished with 'im, why, that feller's twice as fit for hell as you are y'self' (12-13).

The twofold implications existing in Merritt's humorous dialogue have usually been eagerly welcomes by Black and White Australians alike. As an instance, Sweet William's lamentation, "I been stewin' all my life. Ain't made me no better, Rube" is replied by his wife with a smile as "You al- 
ways tasted good to me" (32) - a statement which illustrates the delicate and kind sense of humor in the play. Also in Merritt's play, the colloquial speech abounds in both adults and children's speeches. Merritt's gentle humour is very successful, as when Ruby reproaches his son for being credulous enough to believe in "birriks" (or indiscernible spirit devils). In reply, Pumpkinhead states:

Me and Collie and Noelie seen 'em. Two of 'em, all dressed in black down the church and we were scairt and we run all the way to the mission and we told Uncle Foley and he said they was so! He said they holy birriks and he knows' cos he's wise! (23).

Aboriginality, as represented in Merritt's play, is tantamount to the detection of pleasure in the midst of much agony. As the playwright states, "I was on a suicidal trip of trying to find beauty where beauty is not expected to be found" (qtd. in Shoemaker 244). The playwright does succeed in his aim, for the Black Australian family relationship he depicts is both poignant and convincing. In brief, Merritt urges the European audience to try to see and appreciate the Aboriginality which The Cake Man exhibits (Shoemaker 245).

In Merritt's play, humor is at its zenith at the close of the play. While the audience expects to see what is to happen to Sweet William in Sydney, he is arrested because he is standing near a pub door where the police arrive to quell a brawl:

POLICEMAN: Right you, get your arse in that wagon.

WILLIAM: Who, me? Oh, no boss, I'm down from the bush.

POLICEMAN: Don't you bloody well answer me back!

William is taken away as ridiculously and absurdly as possible, while the music "There's a Happy Land Somewhere" is heard. This music was once again played in the play when the priest was persuading Ruby to convert to Christianity. By playing it at the time of William's ludicrous arrest, the play highlights the injustice of white men towards black community.

\section{CONCLUSUION}

In the end, it should be noted that as a historical work, The Cake Man is full of pointed observations of black/white interracial context in Australia. The play evidently applies postcolonial strategies of negotiations, hybridity, and humor to communicate Aboriginal collective anguish. Yet, the play ignores some of Aboriginal dramatic conventions and moves towards European traditions to make the play accessible to both European and non-European spectators. The prominent feature of Merritt is that he is not interested in applying the Aboriginal linguistic convention to express an understanding of the Aboriginal past. For instance, in the first scene of the work which is explicitly historical the playwright resorts to caricature - in his symbolic typecasting of the colonial agents Priest, Soldier and Civilian and the colonized figures the Aboriginal Man, Woman, and Child - to caricature rath- er awkwardly the joined powers of "God and Gun." In this scene, the Aboriginal characters are either speechless or dead and there is no Aboriginal speech of any kind. The music is also not native but is, as a substitute, a re-working of Western music such as "There's A Happy Land Somewhere." In fact, the opening scene is mostly white in speech, content, and plot. Merritt's strategy of devoting the main part of the work to two soliloquies of Sweet William is also one taken from the Western tradition. In his play, Merritt has deftly assumed the practices of Western theatrical conventions. This means that the playwright seems to be an integrationist who propagate a blance between black and white ideals. Such an integrationism is also proved by Sweet William's attempts to work in Sydney and his occasional confessions about the loss of true Aboriginal identity.

\section{REFERENCES}

Bhabha, Homi K. The Location of Culture. London: Routledge, 1994.

Craven, Rhonda. Teaching Aboriginal Studies. St Leonards, N.S.W.: Allen \& Unwin. 1999.

Goetzfridt, Nicholas J. Indigenous Literature of Oceania a Survey of Criticism and Interpretation. Westport, Conn.: Greenwood, 1995.

Hawley, John Charles, and Emmanuel S. Nelson, eds. Encyclopedia of Postcolonial Studies. Westport: Greenwood Publishing Group, 2001.

Huddart, David. Homi K. Bhabha. London: Routledge, 2005.

Kumaravadivelu, Bala. Cultural Globalization and Language Education. Connecticut: Yale University Press, 2008.

Merritt, Robert J. The Cake Man. Woollahra, N.S.W.: Currency, 1978.

Nayar, Pramod K. Postcolonialism a Guide for the Perplexed. London: Continuum, 2010.

Noonuccal, Oodgeroo. The Dawn is at Hand: Selected Poems. London: Marion Boyars Publishers, 1992.

Riemenschneider, Dieter, and Geoffrey V. Davis, eds. Aratjara: Aboriginal Culture and Literature in Australia. Vol. 28. Amsterdam: Rodopi, 1997.

Runions, Erin. Changing Subjects: Gender, Nation and Future in Micah. Vol. 7. London: A\&C Black, 2001.

Said, Edward. Orientalism. New York: Pantheon, 1978.

Shoemaker, Adam. Black Words, White Page: Aboriginal Literature 1929-1988. Queensland: University of Queensland Press, 1989.

Stanner, W. E. H. Australian Aboriginal Mythology: Essays in Honour of W.E.H. Stanner. Canberra: Australian Institute of Aboriginal Studies, 1975.

Webby, Elizabeth, ed. The Cambridge Companion to Australian Literature. Cambridge: Cambridge University Press, 2000.

Wheeler, Belinda, ed. A Companion to Australian Aboriginal Literature. Rochester: Camden House, 2013. 